\title{
White Food Versus Ethnic Food: Contrasting Food Choices and Intergenerational Family Conflicts in David Wong Louie's The Barbarians are Coming *
}

\author{
Etnik Yiyeceğe Karşın Beyaz Yiyecek: David Wong Louie'nin The \\ Barbarians are Coming Adli Romanında Çelişen Yiyecek Tercihleri ve \\ Kuşaklararası Aile Kavgaları
}

\author{
Elif AYDIN**
}

\begin{abstract}
This study explores the dynamics of the identity construction process in David Wong Louie's The Barbarians Are Coming (2000) in the light of cultural food theories, focusing specifically on the views of Claude Fischler and Deborah Lupton. The study discusses the contrasting food choices and eating habits of the first and second generation Chinese Americans reporting the intergenerational conflicts born by the adherence to American and/or ethnic dietary regimen and their disruptive effect on the family unit. The article argues that food and foodways of Chinese Americans guard the culturally defined Chinese culinary regime against the workings of white dietary practices, but the interaction with a social variable such as class challenges this reserved attitude towards the white palate. The analysis of the novel demonstrates that once the desire of eating is no more tempered by the natural tendencies of the ethnic culinary culture, the appetite gets personalized through nonconforming food practices based on the changing socio-economic position of the characters.
\end{abstract}

Keywords: Food, Identity, Family, Chinese American Literature, Chinese American Novel.

\section{$\ddot{O ̈ z}$}

Bu çalışma, kültürel yemek teorileri 1şı̆ğında, kimlik inşa etme süreci dinamiklerini David Wong Louie'nin The Barbarians Are Coming (2000) romanında incelemektedir. Bu çalışma, özellikle Claude Fischler ve Deborah Lupton'un görüşlerine odaklanmaktadır. Bu çalışma, birinci ve ikinci kuşak Çin kökenli Amerikalıların çelişen yiyecek seçimlerini ve yemek yeme alışkanlıklarını, onların Amerikan ve/veya etnik beslenme düzenine olan bağlılıklarını ve bunun aile birimi üzerindeki yıkıcı etkisinin sebep olduğu kuşaklararası kavgaları göstermesiyle ele almaktadır. Bu makale, Çin kökenli Amerikalıların yiyeceklerinin ve yemek kültürünün, Çin mutfak düzenini beyaz ırkın besidüzeninin etkilerine karşı koruduğunu göstermektedir; fakat beyaz ırkın damak zevkine karşı olan bu savunmacı tutumun, sınıf gibi sosyal bir değişkenle etkileşimi sonucunda sarsıldığını öne sürmektedir. Romanın analizi, yemek yeme isteğinin etnik mutfak kültürünün dayattı̆ğ düzgüsellikten kurtulması sonucunda, iştahın, karakterlerin değişen sosyoekonomik durumuna bağlı olan aykırı yemek yeme eylemleri ile kişiselleştiğini göstermektedir.

Anahtar Kelimeler: Yiyecek, Kimlik, Aile, Çin Amerikan Edebiyatı, Çin Amerikan Romanı.

\section{Introduction}

Food and eating have always been indispensable to our life. Food does not only serve for satisfying our physiological needs but it also plays a great role in determining who we are. Food consumption habits communicate a lot about one's identity and the social group the person belongs to. Taste for certain foodstuffs and distaste for others encode information of the individual's intra-group "habitus" (Bourdieu, 2012, p. 34) which socially marks him/her distinct from people with different food consumption habits. The borders drawn among social groups by food and eating practices activate a centripetal force in constructing one's sense of identity. What we eat, where and with whom we prefer to eat affect the process of our identity formation. Furthermore, because food holds a liminal position (as it is both outside of individuals before its consumption and inside their bodies after its consumption), its

\footnotetext{
* This article is based on the master's thesis "Food as a Sign of Intergenerational Family Conflicts and a Marker of Identity in Chinese American Fiction" defended at Istanbul University, Institute of Social Sciences, Department of American Culture and Literature on March 1st, 2021.

** Res. Asst., Haliç University, Faculty of Arts and Sciences, Department of American Culture and Literature, elifa.95@gmail.com
}

Aydın, E., (2022). White Food Versus Ethnic Food: Contrasting Food Choices and Intergenerational Family Conflicts in David Wong Louie's The Barbarians are Coming, Asia Minor Studies, Cilt 10 Say1 1, 1-15, Gönderim tarihi: 03-05-2021, Kabul tarihi: 06-08-2021.

Araştırma Makalesi. 
consumption naturally affects the body. The substance outside is ingested, and as a result, it becomes a part of its eater. We become what we eat and we prefer to form connections with people who prefer to eat what we eat. Functioning as a language, food (and foodways) encodes messages about the formation of the self and displays the close relationship between its embodiment (eating and/or cooking), identity and the body of the consumer at stake.

Our dietary regimen, which dictates the normal way of eating and determines what is edible and inedible, shapes our identity and marks our position in society. It also determines insiders and outsiders to our group solidarity. By practicing our foodways, we reinforce our normality as opposed to others' abnormal and inacceptable eating habits. We consume specific types of food and reject others as impure and taboo. We practice a certain dietary regimen while we dismiss others. Our performance does not, however, depend on a scripted message. Eating is an unending process of self-assertion. When we abide by the particular culinary rules determined by a social group, we confirm our collective identity and also determine our particular position in society based on it. When we reject them, we reconstruct our identity based on what we decide to incorporate into our system. Our identity construction is therefore an ongoing process. It includes cultural variables such as race and ethnicity. It is open to modifications by means of "incorporation" (Fischler, 1988, p. 279) and "excretion" (Xu, 2008, p. 169). We do not eat what we are told to eat. We instead choose to incorporate certain foodstuff into our body because we want to form our group solidarity with eaters similar to us. Food consumption is therefore significant to our identity construction process. Our identity is not determined by pre-determined positions in society. We reproduce our self based on our changing needs and choices on the dynamic ground of culture.

Food and foodways function as an ethnic sign which confirms our intra-group acceptance but also renders us vulnerable to the racist attacks by members of external groups. Eating and identity formation are processes of continuity. The changes in one affect the other reciprocally. Our identity is therefore constantly reproduced by our food consumption. Also, our (re)produced identity is always subjected to society's judgment based on the parameter of race. Eating ethnic and so becoming ethnic happen to be problematic in white America because the white culinary standard rejects them overtly and/or covertly.

Food can also function as a disruptive mechanism against the family unity. Different food preferences and eating habits of members of the same family can keep them from eating together. The lack of commensality in the family unit damages the bonds between its members since eating together reinforces the sense of togetherness in family. Also, since food consumption is highly important for identity construction, the incompatible dietary regimens of family members can give rise to conflicting identities and family disagreements. These foodbased conflicts can destroy family cohesion and thus result in the disintegration of the family unit.

In this study, David Wong Louie's The Barbarians Are Coming (2000) is viewed at the intersection point of food and class to explore intergenerational identity and family conflicts. Louie's novel can be defined as the best testimony to the paramount function of food in Chinese American literature and its undeniable effect on intergenerational relationships. The Barbarians Are Coming is loaded with numerous food references and images. What is more, its narrative conflict is built upon and perpetuated by differing approaches to comestibles. The novel also features the themes of class and social mobility. It fuels the narrative drive in the story. All the food images and references in the narrative are swathed in these themes.

This study demonstrates that American culinary culture defines ethnic (Chinese) food as wrong food and associates it with the lower class. Chinese food is foreign to the white culinary system so the consumption of this unfamiliar object is presumed to be dangerous for 
the American body. As eating it threatens white identity, the white culinary culture compels its loyal followers to restrain their appetite against it. It is argued here that the protagonist's (Sterling) desire to climb the social ladder impels him to reject the consumption of Chinese food as its ingestion affiliates him with the lower class and so constitutes an impediment before his identification with the white middle class Americans. Once Sterling disciplines his appetite and culinary practices in accordance with the norms and values of the white culinary culture, he becomes able to construct his white identity. However, because his racial qualities continue to mark him as the ethnic other, his culinary membership to the white culture does not improve his socio-economic position or bring him acceptance in American society. It only alienates him from his parents who reinforce their identity through the consumption of ethnic food. This article illustrates that Sterling's and his parents' contrasting approaches to ethnic and white food therefore result in the disintegration of their family.

\section{At the Intersection of Food, Class and Identity: Louie's The Barbarians Are Coming}

David Wong Louie's novel The Barbarians Are Coming was published in 2000. The culinary novel explores the themes of class, family and identity conflicts through food references. It focuses on the everyday life of a typical Chinese American family. The foodrelated events abound in the narrative. They constitute the recurrent family conflicts which function as the driving force of the narrative. These conflicts subvert the stereotypical image of the successful and peaceful Asian American family. This study shows that ethnic Chinese food does not comply with the requisites of the pre-determined white taste. Its unfamiliar and impure nature, which is associated with the lower class palate, poses a threat to the integrity of the upper and middle class white American bodies. Its consumption marginalizes its eater by identifying him with the lower class. I therefore argue that the protagonist's desire for social mobility fuels him to dismiss ethnic Chinese food, which affiliates him with the lower class, and compels him to discipline his food choices and practices based on the workings of the white culinary core. Once the protagonist's cravings are fixated on the consumption of white food, he succeeds in constructing his white identity at the expense of his ethnic culture. However, his compliance with the norms of the white culinary culture does not bring him the satisfaction of his full access to the middle strata or his acceptance since he is a racially and ethnically marked subject in American society. It only destroys his relationship with his immigrant parents who remain loyal to their ethnic culinary culture to confirm their identity.

The novel opens with the protagonist's internal monologue on two striking opposites "Feast or Famine" (p. 3) - to draw attention to the strong interconnection between class and food in the narrative. The protagonist, Sterling Lung, welcomes us as a French cuisine chef, a CIA (the Culinary Institute of America) graduate, at the "Richfield's Ladies' Club" (ibid.). Even though Sterling lives in "the servant's quarters" (p. 29) of Libby Drake's (the club president) mansion and earns his living by serving the white ladies there, he thinks that his position distinguishes him from his immigrant parents whom he deems as "bottom feeders" (p. 154) because of their laundry-business/home. From the beginning, the narrative displays the binary spatial references that foreshadow food and class based family conflicts continuing throughout the story. These references have their basis in the common trope in Asian American literature which Wong (1993) calls as the "immigrant parent/American-born children configuration" (p. $35)$.

Throughout the narrative, Sterling's assimilationist tendencies correspond with his class aspirations. They are most visible in his organization of his diet and eating habits based on the white culinary standard. Sterling carefully whitens his appetite because he associates the white diet and eating habits with the middle class life which has all the privileges he desires. Sterling's strict white diet and cookery trick him into believing that he has achieved the American Dream. 
His illusion compels him to consider his parents as the prototypes of the "forever foreign stereotype" which Cacho explains in her review of the novel as the inevitable plight of Asian Americans in the racist white society (2000, p. 378). Sterling's parents' socio-economic position (the working class) is the reason why Sterling alienates from them and why he abhors their ethnic diet and eating habits.

Louie resorts to class-based food tropes to expose an American-born Chinese's inner conflicts as well as his conflicts with his immigrant parents. His novel abstains from onedimensional representation of these conflicts. The novel is therefore divided into four chapters. The first two chapters provide the first person narration of Sterling's deracination and his conflicts with his parents from Sterling's point of view. These chapters are thus highly intense in displaying the protagonist's justification of his white appetite in face of his immigrant parents" "barbarian" (p. 74) food choices. The third chapter, however, brings a halt to this impetuous self-identification. An omniscient narrator here takes readers to the past and reveals to them Genius's (Sterling's father) struggles as an immigrant in America. The narrative thus discloses how the racist white hegemony determines Genius's socio-economic position in society. The narrator later returns to the present time of the story and focuses on the father-son conflict from Genius's perspective. In this chapter, the omniscient narrator neither tolerates Sterling's deviation nor overlooks his slurs against his parents' Chinese appetite and eating habits. He instead shows how the retention of ethnic foodways becomes a way to protect Genius and Zsa Zsa's (Sterling's mother) ethnic identity. The narrator also presents Genius's counterclaim against his son's degrading labels on Chinese foodways. The narrative here sides with Genius's perspective which does not associate Chinese culinary culture with the lower class status. The contradicting perspectives help readers to see the family conflicts from different angles and thereby have a better understanding of them. They are also significant for understanding Sterling's strong persistence on his mastery over white food and foodways in the last chapter.

Louie's style is also important in delineating the food-based family conflicts between the first and second generations of the Lungs. His down-to-earth realism unveils the restlessness and frustrations lying underneath the experiences of Chinese Americans as a minority group in the white society. His straightforward and quick paced writing style is in harmony with the serious and (mostly) hot-headed tone of the novel. It corresponds to Sterling's class frustration that jeopardizes his relationship with his parents as well as his connection to his roots. Louie's plain language becomes descriptive with food images when the narrative focuses on the dialogues between Sterling and his parents or on Sterling's monologues regarding his disdainfulness of his parents' life style. The Lungs' conflicts are most visible in these scenes.

\section{The "Feast": Identification through White Food and Foodways}

Sterling's desire for upward social mobility starts at a young age. He feels ashamed of his parents' socio-economic status which is symbolized by their "peasant" (p. 222) eating habits. His class anxiety compels him to determine the course of his life by rejecting what seemingly drags him down. In order to achieve his class aspirations, he dispenses with his parents' foodways which he constantly deems as un-American.

After my sister and I visited the nice homes of our American friends, we were shamed and mesmerized by their table manners, by their glasses for cold drinks, cups and saucers for hot, dishes of different sizes for different purposes, the dizzying array of utensils, big and small, the beautiful gilt-edged platters on which food was served. I quickly learned to cut, then transfer the fork to the right hand, then eat. By increments we imported these customs of the table into the laundry, even though they seemed strange, foreign and had made us [...] feel dumb, cloddish, inadequate, like dogs trained to walk on their hind legs, but mimicry, even coarse mimicry - what did we own in the way of dishes, flatware, serving sets, anyway? - was belonging. (Louie, The Barbarians Are Coming, p. 367) 
Sterling identifies American foodways with civility and prosperity. According to him, how and what "real people" (white Americans) (p. 76) eat constitute the norm in society. Adopting their taste buds and copying their eating habits function as practical ways of becoming one of them and thereby affiliating with their socio-economic position. Sterling's desire for the middle class life standards gravitates him toward a palatal training process which corresponds with Lupton's contemplation on tempering the appetite.

In Food, the Body and the Self, Lupton (1996) writes about the concept of "self-mastery" (p. 19) from a food based perspective. She re-interprets Taylor's portrayal of the modern identity as "neo-stoic" (the "rational" self whose behaviors conform to the accepted norm) (ibid.) on the nexus of food and identity. In line with this, she defines "self-mastery" as an individual's ability to discipline his/her food preferences and eating habits based on the accepted norms in society (1996, pp. 19-20). In other words, it is a training process whereby one civilizes his/her appetite and behaviors in accordance with the core values of the hegemony. Sterling's training process starts with his adoption of American table manners. His ethnic acculturation resists against them at first because they differ from what his parents inscribed upon his body before. Sterling, however, continues practicing the American way and succeeds at its mimicry soon after. Yet, his civilization process is still not complete since he has to master over his appetite too.

Sterling soon teaches the white middle "class taste" (Bourdieu, 2012, p. 34) to his palate because it signifies the riches of Americans. In his structuralist reading on tastes and distastes of different social classes, Bourdieu explains his term "class taste" as the categorization of any culinary and alimentary practices based on the values and norms of the social group at stake. The body of the member of the related social group becomes the most prominent sign of it (Bourdieu, 2012, p. 34). Sterling's practicing of American table manners forms the basis of the changes in his body. These changes continue through his palatal training. His adoption of the American (read white middle class) "class taste" disciplines his appetite based on the rules of the white culinary culture and controls his body through policing over what is incorporated into it. His mastery over his dietary regimen chips away his appetite for Chinese food. His selfdiscipline is therefore significant not only for displaying his palatal change but also for marking his deracination.

Sterling's civilized appetite compels him to re-organize his diet based on the workings of the binary classification between white food and ethnic food. This rigid boundary is reinforced by the culinary norms which are defined and (constantly) shaped by the white hegemony. As practitioners of these norms, Americans define white food as familiar and thus clean food. For them, eating it symbolizes normality and acceptability in society. They therefore name it as "'good' food" (pure food) (Lupton, 1996, p. 154). It comes to correspond with concepts such as civilization and wealth in the white nation. On the other hand, Americans do not find ethnic Chinese food familiar because it does not meet the prerequisites of the appropriate food determined by American culinary culture. Since most of Chinese dishes are composed of unfamiliar combinations of various vegetables and animals (including wild ones), the white culinary standard cannot define their ingredients clearly. Their unknown constituents do not comply with the pre-determined white taste. Ethnic Chinese food is therefore defined as impure and undesirable (its exotic nature attracts many Americans but it is never to the extent of its acceptability). Because food consumption affects identity (either by confirming or disrupting it), eating ethnic Chinese food poses a threat to the self-integrity of Americans. The white nation therefore labels it as "bad' food" (the lower class and dirty food) (ibid.) and cautions its people not to eat it. In this sense, the otherization of ethnic food is ensured by the exclusionary working mechanism of the white culinary core. 
In her reading of the novel in Eating Identities, Xu (2008) quotes from Chiu on this matter, "[f]ood's status as either disgusting or delectable has always pivoted in the space of the slash (/), based on human classification by one (dominant) subset of people for their own finicky and fluctuating tastes in a manner that shapes its meanings for other groups of people" (p. 65). In other words, American culinary culture determines what is normal and what can be incorporated into the white American body.

In Sterling's eyes, white food is also the appropriate food because its symbolic value corresponds with the socio-economic status he aspires to achieve. Because eating is a way of becoming and re-affirming one's identity, Sterling feasts on white food to confirm his American self and thereby to affiliate himself with the middle class Americans. His appetite therefore naturally craves for "Drake's Cake and Hostess Twinkies" (p. 64) which are the signs of civilization and prosperity. His food choices are always politically-guided to sustain and advocate the systematic workings of the white culinary center and so the white social order which brings on the classification of its subjects in the first place.

As a strong practitioner of the white diet, Sterling gives his ear to the norms that define ethnic Chinese food as impure and even barbaric. It is embedded in his mind that this food poses a threat to his white identity by means of pollution. In order to preserve his whiteness, Sterling vows to stay loyal to his disciplined appetite and eating manners by turning against his ethnic culinary culture. He therefore comes to abhor his parents' Chinese dishes which he defines as "barefoot food, eat-with-stick food" (p. 75).

Sterling's commitment to his palatal training clearly puts a rigid boundary line between American food and Chinese food. His food classification is found upon his personal class aspirations. It certainly helps him reinforce his white identity, but on the other hand, it results in the marginalization of his ethnic foodways in particular and the otherization of Chinese people in general. Sterling is blind to the fact that his otherization of his parents and their ethnic food actually marginalizes him too. Since he is not one of white Americans but only a replica of them, his deracination will lead to his self-entrapment/victimization.

Sterling's appetite for white food persists because his class envy outweighs his commitment to his roots. In "Food, Food consumption and the Troubled Self', Chang explains the relationship between food, body and desire on selected works from Asian American literature. The part where Chang focuses on the act of eating corresponds to Sterling's persistence: "decisions of eating or not eating certain food, as well as how to eat it, reflect [...] [one's] psychological stat[e] and sense of self: food not only meets the need of [his/her] bod[y], it also feeds [his/her] wants and desires" (2008, p. 361). Sterling fills his stomach by incorporating white food into his system. His food consumption, however, does not only sustain his body. By eating the food of white Americans and copying their eating habits, Sterling also projects a self that marks its difference from the ethnic other.

\footnotetext{
One refrigerator, then the next, opening the doors and looking, but knowing there's nothing in there that I'd want to eat. [...] On a good day, if I'm lucky, I might find a bottle of Coke stuffed among paper bags of oranges, greens, and roots; bundles of medicinal herbs, twigs, bark, berries, and what look like worms bound with pink cellophane ribbon; see-through boxes of black mushrooms and funky salted fish; cloudy plastic wrappers of duck sausage and waxy pork bellies; takeout cartons with scraps of roast pig, roast liver, roast ribs; jars of oysters, shrimp, wood ears, lily buds; and dishes and bowls [...] stacked one on top of the other, teeming with leftovers [...] Under harvest moons, rinse off the maggots, slice, and steam. It is squatting-in-still-water food [...], hooves-in-the-house food. (Louie, The Barbarians Are Coming, pp. 75-76)
}

Each act of food consumption is significant because it directly affects our identity. Eating the right food incorporates its desired properties into our system and thus confirms our sense of self. On the other hand, the consumption of the wrong food pollutes our system by its 
unfamiliar nature and so challenges our identity. Who we think we are is therefore reinforced by our food choices as well as our eating habits. Sterling rummages through in the refrigerator for something like "a bottle of Coke" instead of considering eating the ethnic dishes there because he does not want to pollute his system. He refuses to eat from his parents' refrigerator precisely because it is the potent sign of their "base cuisine" (p. 220). Eating any food from this cuisine would threaten Sterling's identity. His whitened appetite therefore compels him to put a slash between the coke and the ethnic food in the refrigerator. It guards over his mouth against the wrong food.

Sterling's adamancy on his food classification associates him with Colanzi's description of the marginalized person at the kitchen. In her article "The Politics of Food in the Kitchen and at the Dining Table", Colanzi (2008) defines the kitchen "as the place where the disenfranchised attempt to remake themselves into the image of those who reject them" (p. 32). Sterling's envy of the white American lifestyle forces him to dismiss ethnic food and table manners as wrong and inferior. He fits in the image of "the disenfranchised" precisely because his palatal training causes his deviation from his ethnic cuisine and history and leads him to build a white persona for himself.

The most prominent sign of the protagonist's culinary discipline is his profession. Sterling's decision to become a French cuisine chef signifies his rejection of his natural "habitus". According to Bourdieu (2012), an individual's "habitus" is shaped by his/her parental acculturation and socio-economic environment (p. 34). Because Sterling re-constructs it based on his learnings of the white culture and reinforces it through his practice of white foodways, he distinguishes himself from his parents and their socio-economic status. In Sterling's schema, Chinese food corresponds to concoctions of wild animals such as tigers and alligators. His internalized whiteness is judgmental against cooking and eating these types of food. The rules exerted by the American culinary center command Sterling to restrain his appetite against ethnic food. He therefore dismisses it as repulsive and inedible. He likewise avoids cooking this wrong food.

Sterling's rejection of eating and cooking Chinese food shows that he conforms to, what Genius calls, the "America way" (p. 88). Interestingly, Sterling's American "habitus" (Bourdieu, 2012, p. 34) does not gravitate him toward becoming an American cuisine chef. He instead specializes in French cuisine because his Western education has taught him that it is the father of all civilized cuisines. It is associated with aristocracy, wealth and prosperity. It is therefore much superior to American cuisine. Sterling describes it as "the hautest of haute cuisines" (p. 39). Eating and cooking the dishes of French haute cuisine signify its practitioners' higher socio-economic status in society. Lupton (1996) likewise describes the performers of this cuisine as the epitome of the upper strata who knows what the upscale food really is ( $\mathrm{p}$. 21). Since Sterling's culinary discipline is based on civilizing his food choices and practices, he loves to cook French food through which he presents himself as civilized and progressive. By cooking it, he shows that he is neither a practitioner of uncivilized Chinese cuisine nor simply a follower of civilized American cuisine.

The kitchen indeed becomes a place where Sterling disciplines himself and confirms his sense of self. According to Fischler (1988), cookery "construct[s] or sanction[s] [...] the subject's identity" (p. 289). By cooking French food, Sterling identifies himself with the qualities of the haute cuisine. He believes that cooking French food makes him the possessor of good taste in the eyes of Americans. Sterling therefore distinguishes himself from the image of "those Chinese people [...] [who] [p] ut cats in chow mein" (p. 58) via his superior culinary art. His identification process always works on the binary between white food and ethnic food. Since French food is accepted as appropriate in American culinary culture, Sterling secures his 
white identity by cooking it. His cooking, however, culminates in his alienation from his ethnic culinary culture.

Sterling reinforces his civilized/white identity by cooking for the white ladies at the club. The ladies devour what he cooks for them. In "The Unexamined Meal is Not Worth Eating", Heldke comments on the interrelationship between the ingestion of the liminal object (food) and identity. She writes that "in eating, the "not-me" [...] becomes me" (2006, p. 215). The ladies' ingestion incorporates the other (Sterling's dishes) into their bodies literally as well as figuratively. They fill their stomachs literally. They also absorb the qualities of the dishes into their identities since each act of ingestion promises to affect the self either by securing it through familiar foodstuff or challenging it through unknown foodstuff. Sterling's identification with his own cookery becomes a way for him to be one of these whites. He becomes what he cooks, and the white ladies enjoy devouring him by incorporating his familiar dishes into their bodies. Sterling feels that with "every morsel they've ingested molecules of [him] borne on each bite: [He is] bonded to their insides (p. 44). Because the white ladies open their mouths to his dishes, Sterling feels accepted in the social group (the white upper class) they belong to. He thinks that he has finally realized his American Dream through his culinary performances - especially by feeding white Americans. Ironically, Sterling's class envy blinds him to the fact that he has to cook for these white ladies since he is their chef and servant. Unaware of his unacceptance, Sterling's own (class) hunger commands him to continue feeding the white people.

In order to find acceptance in the white society, Sterling continues eating white food and cooking upscale dishes. The protagonist's identification through cooking and eating affiliates him with Mannur's term "culinary citizenship" which is explained in her article "Culinary Nostalgia: Authenticity, Nationalism, and Diaspora" in 2007. According to her, it is "a form of affective citizenship which grants subjects the ability to claim and inhabit certain subject positions via their relationship to food" (2007, p. 13). Sterling comes to align himself with white Americans because his culinary practices conform to the norms of American culinary culture. Sterling's ingestion of white food clears his system from the undesired properties of ethnic food. Sterling therefore establishes a culinary affiliation with the white middle class by means of discipline and mimicry.

Sterling's culinary connection with American culture disavows his "descent" based relationship (Sollors defines it as affiliations based on consanguinity) (Sollors, 1986, p. 151) with Chinese culture. His whitened appetite and practices (eating habits and cookery) point at his volitional affiliation, or his "consent" based relationship in Sollors' words (ibid.), with American culture. Sterling's volitional affiliation reconstructs his cultural identity based on the white ethnic core. His alimentary and culinary practices function as the agents of reinforcement of it. They however negate his ethnic identity which reveres Chinese food and foodways. The more Sterling eats and cooks white food, the more he alienates from his roots. The incorporation of whiteness transforms him within. Sterling's parents are troubled by this transformation. His deracination eventually becomes the source of his parents' pain.

Sterling's palatal training compels him to incorporate solely white food into his body. According to Fischler's "incorporation principle", each act of ingestion encodes a message to the self as well as to others $(1988$, p. 277). The protagonist's consumption of white food tells him that he is an in-group member of the middle class America. On the other hand, it tells his parents that he is a "juk-sing" (assimilated American-born Chinese) (p. 115) who is ignorant of Chinese culture and cuisine.

Sterling's diet gives rise to conflicts in the Lung family. It is because Sterling transgresses the boundaries of Chinese culinary culture by incorporating American food into 
his system. His predisposition toward whitening his palate reveals itself from a young age. It becomes the most prominent determinant of his distinction from his parents who are the members of Chinese culinary culture. Louie depictures a Thanksgiving dinner at the Lungs' place to show this distinction by pointing at the incompatibility between the two generations' understandings of this American tradition.

\begin{abstract}
It just never was in their bones. No turkeys in China. [...] But for all the years of elementary school, my teachers inculcated me with the holiday. [...] Thanksgiving meals he [Genius] cooked were [...] Chinese. Served in grand Chinese style, on makeshift plywood tables, the brown paper used to package customers' laundry doubling as tablecloths. Rice bowls and chopsticks. The turkey, chopped into each-by-two-inch chunks, was parked next to bird's-nest soup, mung bean threads, sautéed abalone. The spread looked nothing like it was supposed to, nothing like Thanksgiving on TV, the turkey brought whole to the table, drumsticks wearing paper crowns, keeping company with stuffing, canned yams, celery sticks, cranberry sauce, pumpkin pie. In the end, I blamed my father for ruining Thanksgiving. (Louie, The Barbarians Are Coming, pp. 134-135)
\end{abstract}

Sterling's white indoctrination earns him a different value system than his parents'. He therefore looks at his father's version of the Thanksgiving dinner from a different perspective that conforms to the American culinary standard. From Sterling's perspective, his parents do not know the norm for the occasion. According to the white culinary order, eating turkey is the norm for Thanksgiving dinner. Eating red meat or seafood would mean deviation from the Thanksgiving normativity. Sterling abhors his parents' food choices for the occasion and abstains from eating their dishes because incorporating them into his body would pose a threat to his white identity.

Lupton's remark about the relationship between food, revulsion and identity can be borrowed to explain Sterling's behavior: "revulsion for the food eaten by another is [...] a means of distinguishing between social groups" (1996, p. 35). By detesting and dismissing his parents' understanding of Thanksgiving dinner, Sterling distinguishes himself from "the Chinese peasants" (he calls his parents as such) (p. 179) and their lower class cuisine.

The differing culinary value systems of Sterling and his parents present two different views on turkey meat. While the white culinary order defines it as good and nutritious, Chinese culinary culture does not revere it as much as red meat or seafood. Turkey is served as the main dish on the dinner table of white Americans, but it becomes one of the side dishes on the table of Chinese people. Sterling's whitened palate naturally craves for turkey meat, but for his parents, it is "bad-eating" (p. 134) since it is "coarse and dry" (ibid.). According to them, "[o]nly stupid Americans eat turkey" (ibid.). Genius knows that his son is one of them so he buys turkey meat only because of it. Genius and Zsa Zsa's full blast refusal of Sterling's understanding of Thanksgiving dinner signifies their loyalty to their ethnic cuisine. It points at their culinary efforts to police the borders of Chinese culinary culture. Genius and Zsa Zsa preserve their ethnic acculturation because their identities are defined by it. Practicing Chinese culinary culture becomes a way of self-assertion for them. Also, in line with Mannur's remarks about the meaning of ethnic food practices to immigrant generations, Genius and Zsa Zsa hold onto Chinese foodways because it functions as a "palliative for [their] dislocation" (2007, p. 13).

The concept of ethnicity presents a set of pre-determined values to its followers. Culinary practices (such as cooking and table manners) function as agents of their reinforcement. The systematic consumption of ethnic food also validates these values. By eating and practicing the ethnic, individuals continuously affirm their ethnic identity and community membership. The Lung family, however, fails to form a consolidation based on their ethnic values. The Lungs' non-stop quarrels are always rooted in the two generations' differing approaches to their ethnicity that result in the incompatibility of their dietary regimen. 
According to Kalčik's classification of three different types of performers of ethnicity, Sterling and his parents fall into different categories. Sterling fits in the first category of performers who choose "Americanism" (Kalčik, 1984, p. 56) over an unconditional commitment to the roots. His parents are, on the other hand, the members of the second category which Kalčik defines as the community of persons who prefer to stay loyal to their ethnic origin. Neither Sterling nor his parents come up to the third category which applies to people who can negotiate their ethnic and American identities with a pluralistic perspective. Sterling clearly internalizes American values and thus breaks off his relation with his roots. His (Chinese) food loathing becomes the most apparent sign of his rejection of ethnic values and norms. As a result of it, he comes to see his parents as alien immigrants who eat weird foodstuff.

Genius and Zsa Zsa likewise disregard the idea of negotiation. Unlike their son, however, they hold onto their ethnic culture and reinforce their identity by means of it. Their cultural conservatism impels them to turn down the white food their son desperately craves for. Their consumption of ethnic food indicates their strong resistance to assimilation. Genius and Zsa Zsa's ethnic shield comes to define their son as "crazy juk-sing" (crazy American) (p. 181) who is an outsider to their community.

Louie resorts to food references and images to sustain the narrative drive which is based on family conflicts. Throughout the narrative, food is always used as a sign of difference between the first and second generation Chinese Americans. The different dietary regimens of Sterling and his parents come to signify their differing worldviews - especially on assimilating into American society. Their contrasting approaches to ethnic and white food give rise to serious conflicts in their family.

The Lungs' conflicts always work on the parameter of good taste. From Sterling's perspective, Genius and Zsa Zsa's immigrant origin shapes their taste buds. Therefore, they are not acquainted with white food. They consequently do not know what good taste really means. Sterling associates good taste with refinement which is symbolized by American and (mostly) French food. Hence, he even turns down his mother's offer for a cup of traditional Chinese tea saying "I don't want any of that" (p. 84). His rejection of ethnic food and/or drink signifies his rejection of the Chinese palate which denotes the lower class. Most importantly, it indicates his rejection of his parents and his deviation from his roots.

On the other hand, Genius and Zsa Zsa do not waver in face of their son's rejection. They do not adopt Sterling's definition of good taste. They instead stay loyal to their ethnic domestication that defines good taste as homemade Chinese food. Sterling's and his parents' contrasting definitions of good taste perpetuate their conflicts. Food therefore works as a disruptive parameter against the cohesion in the family. In Sahlin's words on the relationship between food and social relations, "food is employed instrumentally as [...] a destroying mechanism of sociability" (qt. in Lupton, 1996, p. 37). The different food choices and eating habits of the Lungs keep them from communicating and understanding one another.

The narrative unveils scenes that delineate the family conflicts based on the discordant understandings of good taste. In these scenes, the notion of good taste is extended to food presentation. Sterling's and Zsa Zsa's different perspectives on food presentation inflame the conflicts in the family. Sterling's white identity highly reveres food presentation. According to the white culinary culture, if food is appealing to the eye, it would be more appetizing. It affiliates visual satisfaction with good taste. Sterling's loyalty to the white culinary center turns him to a master who prepares visually satisfying dishes for his diners. He "douse[s] the tarte Tatin with Grand Marnier and cognac, [...] ignite[s] one of the cakes, then exits the kitchen, a crown of blue flames in [his] hands" (p. 46) for the sole purpose of satiating white Americans 
who are ready to eat with their eyes. Sterling accomplishes his mission since his diners let out their satisfaction through their ecstatic exclamations.

Genius and Zsa Zsa's understanding of food presentation highly differs from their son's. According to their culinary culture, the availability or accessibility of food is more important than its presentation. If there is a home-cooked Chinese meal (no matter how modest it is) on the dinner table, it surely possesses the requisite qualities of good taste. Genius and Zsa Zsa therefore do not understand their son's insistence on glamorizing the objects which are only needed for satisfying the physiological needs of the body. For them, the sustenance of the body is more important than pleasing the eye.

Genius and Zsa Zsa's prioritization of the body is due to their immigrant life conditions. These conditions determine their socio-economic position in society by affiliating them with the working class. Since their position enables them to work only at menial jobs, Genius and Zsa Zsa work at the laundry. They use their bodies because the job requires a great amount of physical work. Physical durability is therefore significant for them. Their approach to food is consequently shaped by a mindset that focuses on the restoration of the body. They do not care "how food is served, just as long as there is food to serve" (p. 367). For Genius and Zsa Zsa, food serves as an instrument of survival. They do not have the luxury of getting entertained by the appearance of food.

The differing views on food presentation give rise to bitter arguments between Sterling and his parents. Since Sterling's disciplined appetite craves for white food and his white culinary indoctrination values the civilized dining etiquette, he grows bitter at his mother's ethnic dishes served in communal pots and pans. He hates that "Zsa Zsa rarely bothered to transfer [her food] from the steam pan to a serving dish" (p. 367). For Sterling, Zsa Zsa's unconcernedness to food service/presentation becomes a sign of her lower class status and thereby her uncivilized nature. He therefore abstains from sitting around his mother's dinner table and eating her dishes. He comes to detest Chinese culinary culture which only reveres the physical satiety of its practitioners almost in a barbaric manner. Sterling shows his disapproval of his mother's (as well as his father's) uncivilized food presentation by paying extra attention on the appearance of his dishes. He denigrates his parents' definition of good taste by calling it "medieval" (p. 105). As a result of his internalization of the American culinary norms, Sterling becomes an "odd person" (p. 234) in his parents' eyes. His persistence on food presentation/glamorization enrages them to a great extent.

\section{The "Famine": Rejection by the White Hegemony}

In the narrative, Sterling's realization of his socio-economic position (a cook/servant in the white society) is a pivotal point that comes to affect the course of the family conflicts sharply. Once Sterling understands that he does not belong to the white middle class America and that it is his illusion that affiliates him with true Americans, he becomes desperate to realize his American Dream. He understands that his self-discipline is not enough for him to become one of white Americans. His whitened appetite and table manners point at his mimicry of the world he is not a part of. In order to realize his class aspiration and thereby distinguish himself from his parents and their lower class status, Sterling resorts to another type of (food-centered) mimicry - acting like "a goofy bucktoothed immigrant [Chinese chef] who is humbled and grateful" (348) for having been let into America. In line with Cacho's review of the book, Sterling "compl[ies] with culturally racist dominant narratives of Asians in order to achieve socioeconomic "success"" (2000, p. 378). To put it another way, in order to climb the social ladder, Sterling establishes a culinary relationship with his ethnic culture by means of his exploitation of it. 
White Americans associate exotic food (ethnic food) with visual satisfaction/satiation. It is their way to exploit ethnic cuisines (and cultures). In his article "Boutique Multiculturalism", Fish (1997) defines cultural colonizers as "boutique multiculturalists" (p. 378). According to him, they exploit foreign cultures by trying out their foods, clothing and any other cultural practices while posing as multiculturalists. Their adventures satiate their stomachs and their eyes. Their openness to different ethnicities/cultures appears as an act of charity. Despite its inclusive approach toward the other on the external level, it actually works on his/her exclusion by means of his/her (further) marginalization. In line with Fish's definition, the novel's white characters can be seen as "boutique multiculturalists" because they literally push Sterling to cook (exotic) Chinese food for them. They desperately crave for it just to appease their eyes. Their hungry gaze is an invitation to Sterling. Knowing this, Sterling grabs his chance to appease their hunger in order to find acceptance in the white society.

Upon his father-in-law's demand (a white upper class Jewish man), Sterling starts his TV show to prepare exotic Chinese dishes for white fake multiculturalists. He becomes an insider of Chinese culinary culture by cooking Chinese food. Adopting Browder's words, Sterling's "ethnic impersonation" (qt. in Dalessio, 2008, p. 422) of a Chinese chef gives him an access to his ethnic culture. However, his insider position does not make him a real practitioner of Chinese culinary culture. His affiliation with it is not based on his sincere feelings, but rather, it is motivated by his objective to satisfy his white viewers' appetite for exotic (and most importantly palatable) Chinese food and to obtain their love and affection. Sterling therefore manipulates his insider position and gives his white exploiters what they want to see: a humble and timid (and most importantly foolish) immigrant who cooks mysterious dishes from the Middle Kingdom. Sterling knows that, in his daily life, he is "not the kind of Chinese that viewers want to see" (p. 348) so he learns to "act" (p. 298) like one to please them. Sterling's acting of the stereotypical image of the Chinese turns him to a comical figure who is after his American Dream at the expense of his ethnic heritage.

Sterling becomes a TV star by exoticizing the ethnic Chinese recipes he snatches from his mother. With their exotic names and familiar (safe) ingredients, his Chinese dishes conform to white Americans' definition of exotic food. Motivated by his desire for social mobility, he presents a glamorized version of "the plebeian fare the masses apparently want" (p. 210). His food presentation appeals to the white public precisely because of its focus on exoticization and palatability. Rosalind Coward's re-definition of Chin's term "food pornography" (qt. in Lupton, 1996, p. 24) can be borrowed here to explain whites' attention on the appearance of exotic food. According to her re-definition, the term comes to mean that food functions as a source of gratification through the pleasurable sensations its appearance ensures (ibid.). Sterling's food presentation offers his white viewers the chance to experience "food pornography" (ibid.) through their consumption of the visuals of his exotic dishes. He therefore succeeds in appeasing the hunger of white fake multiculturalists.

Sterling's "famine" (class envy) (p. 3) is not satiated by feeding his white viewers. It is because their (visual) consumption of his dishes does not bring his acceptance in American society. Their consumption corresponds with their exploitation of his ethnic culture and its members. As a racially and ethnically marked subject, Sterling is therefore manipulated by the white masses. His compliance with whites' understanding of Chinese food does not award him with their approval. As a result of it, Sterling does not pass as one of true Americans.

Sterling shows his awareness of his exploitation in one episode of his TV show. During his acting, Sterling suddenly drops his comical persona when he spots a well-known ingredient on the kitchen counter: salt. By means of collective memory that ensures his momentary acceptance of his ethnic culture, Sterling starts telling the history of salt looking directly at his 
white audience through the camera. His version of the history of salt differs from what his Western education has embedded in his mind. He rejects the white metanarrative on salt by remembering a suppressed history and exposing it to his audience. He looks at the camera and tells his white viewers, "salt was invented by the Chinese [...] The Chinese were the first to cultivate salt. We flooded fields with seawater, and after its evaporation, we harvested the remaining crystals from the soil" (pp. 332-333). Sterling's awareness of the silenced history and his use of collective "we" here initially indicate his possible return to his roots as they point at his affiliation with Chinese field workers. Remembering the origin of salt, which is the "staple of life" (p. 332), offers Sterling a chance to re-establish his ties with his ancestors as well as with his parents. However, despite the momentary insubordination to the white rhetoric and rule, Sterling's re-telling does not result in his full acceptance of his ethnic culture and history. His recollection of the forgotten is not enough for him to embrace his ethnic identity unconditionally.

Sterling's rejection by the white hegemony does not wear him down. He continues to bow down to the white norms and perform the white culinary practices. His unwavering loyalty to American culinary culture exasperates his parents. His exotic food presentation on TV disturbs them especially. Genius and Zsa Zsa comprehend neither the dishes Sterling cooks nor the character he plays on TV because their culinary enculturation does not recognize them. Sterling's and his parents' conflicts over food and food presentation come to break the fragile bonds between them.

In the narrative, the disintegration of the Lung family becomes most apparent through the absence of commensality. From the beginning until the very end, there is not even one scene in the narrative where all the members of the Lungs come together around the dinner table. Eating together is an important factor in sustaining the sense of togetherness in the family unit. In the domestic realm, family members confirm and reinforce their identities by gathering around the dinner table and sharing food that appeals to their (common) taste buds. The act of commensality reveals the changing relationships and subject positions in the family. Therefore, as Lupton (1996) states, '[t]he 'family meal' and the 'dinner table' are potent symbols, even metonyms, of the family itself' (p. 39). Throughout the narrative, Sterling and his parents never share food in the private or the public realm. Their contrasting definitions of the appropriate food and conflicting understandings of good taste keep them from gathering around the dinner table. The absence of commensality in the Lung family breeds the absence of their family unity. The Lungs' dinner table reveals the extent of their conflicts and points at their insolubility. It therefore signifies the family members' alienation from one another. It also shows that the Lung family deviates from the social norm that associates the concept of family with the sense of togetherness.

Throughout the narrative, Sterling does nothing to improve his relationship with his parents. His class shame impels him to stay away from them. He therefore remains devoted to his palatal training and continues to mark his difference from them especially by cooking white food. Sterling's cookery becomes the potent sign of his character. Since cooking offers a process of "culturing" (Lévi-Strauss, 2012, p. 41) based on the specific rules of the cuisine at stake, Sterling comes to cultivate his identity through his white cookery. In other words, Sterling uses his cooking skills to continuously affiliate himself with the white middle class despite its rejection of him.

Fischer's reflection on the relationship between cookery and identification is significant to understand Sterling's identification process. According to her, "cookery [...] give[s] [...] a place in the world, a meaning" $(1988$, p. 286). By assimilating into the white culture and abiding by its norms of cooking, Sterling shows his determination to improve his socio-economic 
position in American society. His identification through his white cookery results in his disownment of a part of himself (his ethnic identity) which is not recognized by his cultural (American) identity. At the end of the narrative, Sterling therefore still does not share his parents' understanding of ethnic food and foodways.

In the last scene of The Barbarians Are Coming, Sterling rustles up "Genius's cracker stew" (p. 371) for Moses's (his son) sake. While serving it to his son, he introduces it as a Chinese dish of which recipe Genius brought from his home country. Sterling's cooking of the 'ethnic food' initially shocks readers as it signifies a sharp twist that can disrupt his white identity by polluting it. However, at that moment, Sterling discloses the fact that the ingredients of the concoction are "just flour, water, sugar, milk, and salt" (p. 372), the mass produced products, which are bought from American supermarkets. Hence, there is not any sign of it to ensure that it is an ethnic dish. In his ignorance of Chinese culinary culture, Sterling comes to believe that the concoction is authentic Chinese and so tells his son that it is "[t]he real thing" (ibid.). Sterling's understanding of the concoction (and ethnic food in general) completely differs from his father's understanding of it. Genius fixes this concoction on his modest dinner table when he arrives in America for the first time. It is born out of his socio-economic condition in society, and it has therefore no connection with Chinese cuisine. Sterling's inaccurate redefinition of it as authentic Chinese food marks his difference from his father and points at his deracination. It indicates that he guards himself against Chinese culinary culture, and as a result, he is not aware of the requisite qualities that identify ethnic food. At the end, Sterling still shows his adamancy on white food and foodways. Because it is the only way for him to pose as a real American.

\section{Conclusion}

Food is an indispensable object for humankind. It is occasionally dismissed as an everyday normality. Our consumption of food is not only for our physical sustenance. Our food practices (food preferences, cooking styles and eating habits) work to confirm our sense of self besides alleviating our hunger. Since each act of ingestion is a way to become, we keep on affirming our identities by eating the culturally appropriate food. Our manners of eating also reinforce our identities by marking our distinction from people with different eating habits. Being highly symbolic, our food preferences and eating habits always disclose who we are, or who we choose to become.

Louie's The Barbarians Are Coming has been reviewed by unearthing its kaleidoscopic food and class references. I have initially pointed out that Chinese food is foreign to the white culinary system and so it threatens the white American body with pollution. It has been underlined that Chinese food is defined as the lower class food, and its consumers are stigmatized through its inferior status in the white society. I have argued that Sterling's aspiration to move up the social ladder impels him to dismiss the ethnic lower class food, which contaminates his identity, and forces him to discipline his appetite and culinary practices based on the norms and values of the white culinary center. Sterling's adoption of the American diet and eating habits whitens his identity but it does not grant him full acceptance in American society. Even if he does not pass as one of white Americans, his white culinary performances still mark his difference from his parents who are identified by their consumption of the lower class food/ethnic food. My analysis has also shown that Sterling's and his parents' different culinary membership gives rise to serious conflicts in their family.

\section{Bibliography}

Barthes, R., (2012). Toward a psychosociology of contemporary food consumption. In C. Counihan and P. V. Esterik (Eds), Food and culture: a reader, 23-30: Routledge. 
Bourdieu, P., (2012). Distinction: a social critique of the judgement of taste. In C. Counihan and P. V. Esterik (Eds), Food and culture: a reader, 31-39: Routledge.

Cacho, L. M., (2000). Review of Hunger, The Barbarians Are Coming. Journal of Asian American Studies, 3, 378-382.

Chang, Y. I., (2008). Food, food consumption and the troubled self in Kingston's The Woman Warrior, Walker's The Color Purple, Tan's The Joy Luck Club, and Erdrich's Love Medicine. A. M. Magid (Ed), You are what you eat: literary probes into the palate, 345-366: Cambridge Scholars Publishing.

Colanzi, R., (2008). Marginalization, inclusion, and social transformation: the politics of food in the kitchen and at the dining table. A. M. Magid (Ed), You are what you eat: literary probes into the palate, 27-43: Cambridge Scholars Publishing.

Dalessio, W., (2008). The joy of cooking and eating: cultural hybridity and female empowerment in Oreo and Mona in the Promised Land. A. M. Magid (Ed), You are what you eat: literary probes into the palate, 409-446: Cambridge Scholars Publishing.

Douglas, M., (1972). Deciphering a meal. Daedalus, 101, 61-81.

Fischler, C., (1988). Food, self and identity. Social Science Information, 27, 275-292.

Fish, S., (1997). Boutique Multiculturalism, or why liberals are incapable of thinking about hate speech. Critical Inquiry, 23, 378-395.

Gabaccia, D. R., (2000). We are what we eat: ethnic food and the making of Americans. Harvard University Press.

Georges, R. A. (1984). You often eat what others think you are: food as an index of others' conceptions of who one is. Western Folklore, 43, 249-256.

Heldke, L., (2001). "Let's eat Chinese!": reflections on cultural food colonialism. Gastronomica, 1, 76-79.

, (2006). The unexamined meal is not worth eating. Food, Culture \& Society, 9, 201219.

Kalčik, S., (1984). Ethnic foodways in America: symbol and the performance of identity. L. K. Brown and K. Mussell (Eds), Ethnic and regional foodways in the United States: the performance of group identity, 37-65: University of Tennessee Press.

Lévi-Strauss, C., (2012). The culinary triangle. In C. Counihan and P. V. Esterik (Eds), Food and culture: a reader, 40-47: Routledge.

Louie, D. W., (2000). The barbarians are coming. New York: G.P. Putnam's Sons.

Lupton, D., (1996). Food, the body and the self. SAGE Publications.

Mannur, A., (2006). Asian American Food-Scapes. Amerasia Journal, 32, 1-5.

, (2007). Culinary nostalgia: authenticity, nationalism, and diaspora. MELUS, 32, 11-31.

, (2010). Culinary fictions: food in South Asian diasporic culture. Temple University Press.

Sollors, W., (1986). Beyond ethnicity: consent and descent in American culture. Oxford University Press.

Wong, S. C., (1993). Reading Asian American Literature: from necessity to extravagance. Princeton, New Jersey: Princeton University Press.

Wu, F. H., (2002). Yellow: race in America beyond black and white. New York: Basic Books.

Xu, W., (2008). Eating identities: reading food in Asian American Literature. University of Hawai'i Press. 